\title{
CSR and RRI - overlapping or complementary management concepts?
}

\author{
Agata Sudolska (iD) \\ Nicolaus Copernicus University
}

Dorota Grego-Planer

Nicolaus Copernicus University

\section{Introduction}

Nowadays, there is widespread concern about responsibility in business. This has led to increasingly strong legislation, international environmental management standards, the appearance of new metrics and reporting standards, etc., which force firms to adopt new approaches to remain competitive. In these times of ongoing climate changes, customers are shifting their preferences toward more sustainable offerings. The growing awareness of the social and environmental problems has resulted in the necessity for enterprises to build their capabilities which recognise and respond to the emerging opportunities and threats through linking the issues of responsibility and sustainability with innovation processes ${ }^{1}$. Therefore, companies today focus on integrating the principles of responsibility into their competitiveness, economic growth and technological progress. Given such a perspective, the Corporate Social Responsibility (CSR) concept as well as the Responsible Research and Innovation (RRI) concept provide firms with a framework and tools enabling them to integrate responsibility into their business strategies and operations. Both concepts (though firms are much less familiar with the RRI approach than with the CSR concept) aim to increase businesses' awareness of specific ethical issues and aspects of responsibility connected to their operations, including their innovation processes. Thus, the aim of this paper is to explain the ideas of CSR and RRI, focusing on the concepts' similarities and differences as well as the possibility

1 R. Heinberg, Peak Everything: Waking up to the Century of Decline in Earth's Resource, Clairview, London 2007, p. 42. 
to integrate them in business practice. In our paper we focus on understanding both concepts in terms of linking being responsible in business contexts with creating innovations that are ethically acceptable and socially desirable.

The research is based on a literature review and aims to provide a critical assessment of the reasoning behind the integration of CSR and RRI in a business context. The research process is oriented to the following research questions:

1. "How are the CSR and RRI concepts defined?";

2. "What are the overlaps and differences of the CSR and RRI concepts?";

3. "How can the CSR and RRI concepts be integrated in a business context?".

We applied the method of a literature review in order to search for the responses to the aforementioned research questions, thereby achieving the aim of the paper.

\section{Innovation and responsibility}

Nowadays, researchers emphasize the need for interconnection between two areas whose importance is recognized by managers, policy makers as well as scholars: innovation studies and business studies on responsibility ${ }^{2}$. Essentially, firms being responsible is their willingness to incorporate broader social and environmental aspects into their strategies, while being accountable for the impacts of their decisions and activities on society and the environment. The way people think today from the perspective of responsibility in innovations is changing to reflect the modern context in which innovations occur ${ }^{3}$. In general innovation is perceived as innately good. Nevertheless, there is always a probability that a particular innovation will cause unexpected effects. Today, we realise that even the most favorable innovation may fail owing to a particular ethical or societal anxiety which was not taken into consideration when considering the implications of an innovation ${ }^{4}$. In turn, the scope of responsibility in regard to innovations goes beyond legal requirements and business standards and encompasses the expectations of stakeholders and values related to the society and the natural environment that are required in the particular markets where innovations are planned to be implemented ${ }^{5}$. With the above in mind,

2 C. Groves, Future ethics: risk, care and non-reciprocal responsibility, "Journal of Global Ethics" 2009, vol. 1, no. 5, p. 19; R. Von Schomberg, A vision of responsible research and innovation, [in:] R. Owen, J. Bessant, M. Heintz (eds), Responsible Innovation, Managing the Responsible Emergence of Science and Innovation in Society, Wiley, New York 2013, p. 56.

3 B. Adam, C. Groves, Futures tended: care and future-oriented responsibility, "Bulletin of Science, Technology \& Society" 2011, vol. 1, no. 31, p. 18.

4 M.I. Leone, P. Belingheri, The relevance of Innovation for Ethics, Responsibility and Sustainability, "Industry and Innovation" 2017, vol. 5, no. 24, p. 438.

5 A. McWilliams, D. Siegel, P.M. Wright, Corporate social responsibility: strategic implications, "Journal of Management Studies" 2006, vol. 1, no. 43, p. 9; R. Von Schomberg, A vision 
both CSR and RRI concepts are extremely useful, as CSR can be a means of reducing risk: firms implement CSR to reduce risks associated with legislation or stakeholders. Although it is sometimes criticized as a short-term, limited, view of CSR, the important thing is to get firms to begin to take the idea of responsibility into consideration while planning their strategies, including in regard to innovations ${ }^{6}$. In this context the RRI concept explicitly links innovation and responsibility ${ }^{7}$. This means that existing responsibilities need to be addressed as a whole, framing responsible innovation as impacting society at large, with closer attention to the societal context as well as the broader spectrum of actors capable of reflecting their own values on research and innovation-related responsibilities ${ }^{8}$.

\section{The idea of the Corporate Social Responsibility (CSR) concept}

Despite the CSR concept interesting researchers from several disciplines ${ }^{9}$, the concept is not clearly defined either in the literature or in practice. It is an ambiguous term, perceived differently by different people, as this idea covers a wide range of aspects. Even the governing bodies and regulators differ in their perception of CSR. The European Commission defines CSR as "the responsibility of enterprises for their impacts on society"10. The World Business Council for Sustainable Development explains CSR as "the commitment of business to contribute to sustainable economic development, working with employees, their families, the local community and

of responsible research..., p. 59.

6 R. Owen et al., A Framework for Responsible Innovation, [in:] R. Owen, J. Bessant, M. Heintz (eds), Responsible Innovation. Managing the Responsible Emergence of Science and Innovation in Society, Wiley, New York 2013, p. 32.

7 A. McWilliams, D. Siegel, P.M. Wright, Corporate social responsibility..., pp. 1-18.; A. Gurzawska, M. Makinen, Ph. Brey, Implementation of Responsible Research and Innovation (RRI) Practices in Industry: Providing the Right Incentives, "Sustainability" 2017, vol. 9, 1759.

8 Ibidem.

9 M.E. Porter, M.R. Kramer, Strategy and society: The link between competitive advantage and Corporate Social Responsibility, "Harvard Business Review" 2006, vol. 12, no. 84, p. 88; D.M. Boehe, L. Barin-Cruz, Corporate Social Responsibility, product differentiation strategy and export performance, "Journal of Business Ethics" 2010, no. 91, p. 325; K. latridis, D. Schroeder, Responsible Research and Innovation in Industry. The Case for Corporate Responsibility Tools, Springer, London 2016, p. 32.

10 European Commission, Communication from the Commission to the European Parliament, the Council, The European Economic and Social Committee and the Committee of the Regions. A renewed EU strategy 2011-14 for Corporate Social Responsibility, Brussels 2011, https://eur -lex.europa.eu/legal-content/EN/TXT/PDF/?uri=CELEX:52011DC0681\&from=EN (accessed: 5.12.2019). 
society at large to improve their quality of life"11. Moreover, the approaches to explain CSR in the academia lack a consensus. According to McWilliams and Siegel, CSR should be understood as "actions that appear to further some social good, beyond the interests of the firm and that which is required by law"12. It is also proposed to define CSR as a group of actions undertaken by companies in order to accept the responsibilities resulting from the impact of its activities on society and the environment or take ownership of the negative externalities they generate ${ }^{13}$. Another stream explains CSR as a stakeholder driven concept. In line with the stakeholder theory, the company may benefit from engaging in certain CSR activities that stakeholders perceive as important. Taking such a perspective, CSR is understood as a firm's response to stakeholders' needs, involving activities that are voluntary by definition, demonstrating the inclusion of social and environmental concerns in business operations and interactions with a firm's stakeholders ${ }^{14}$. CSR may be also defined as a comprehensive business model designed to meet the requirements and expectations of the various stakeholders of a firm, as well as to care for and preserve the environment ${ }^{15}$. As highlighted by Chakaraborty et al., CSR is a means of achieving a firm's commercial success in ways that honor ethical values, respect people, communities and the natural environment, and encompass all those actions of the organizations which affect society and its well-being 16.

The CSR concept is based on three pillars: social, economic and environmental ${ }^{17}$, on which all activities conducted by an organization can be divided into two: internal and external. The first mentioned category includes the issues of employees' welfare and safety, work environment and intellectual property, whereas the latter category covers environment protection, the quality and safety of a firm's

11 World Business Council for Sustainable Development, World Business Council for Sustainable Development, Corporate social responsibility: Meeting changing expectations, New York 1999, p. 11.

12 A. McWilliams, D. Siegel, Corporate social responsibility: A theory of the firm perspective, "Academy of Management Review" 2001, no. 26, p. 117.

13 A.B. Carroll, Corporate social responsibility: Evolution of a definitional construct, "Business \& Society" 1999, vol. 3, no. 38, p. 290; S.S. Taneja, P.K. Taneja, R. Gupta, Research in corporate social responsibility: A review of shifting focus, paradigms and methodologies, "Journal of Business Ethics" 2011, no. 101, p. 347.

14 K. Basu, G. Palazzo, Corporate Social Responsibility: A Process Model of Sensemaking, "Academy of Management Review" 2008, vol. 1, no. 33, p. 122.

15 M. Van Marrewijk, Concepts and definitions of CSR and corporate sustainability: Between agency and communion, "Journal of Business Ethics" 2003, no. 44, p. 103.

16 S.K. Chakraborty et al., Management paradigms beyond profit maximization, "The Journal of Decision Makers" 2004, vol. 29, no. 3, p. 107.

17 S. Benn, D. Bolton, Key Concepts in Corporate Social Responsibility, Sage Publications, London 2011, p. 11. 
products, and relations with suppliers and communities ${ }^{18}$. Being a multifaceted concept, CSR encompasses various activities that companies may undertake. Examples of CSR include supporting the local community, participation in charitable events, promotion of non-discrimination activities, expansion of employment benefits, operating efficiency, minimizing pollution, transparency, product safety, and generating profits ${ }^{19}$. However, regardless of the type of activities undertaken by firms engaged in CSR, the main challenge refers not to the definition of the concept but to incorporating CSR into a company's strategies, business operations and their interactions with stakeholders.

\section{The idea behind the Responsible Research and Innovation (RRI) Concept}

The relevant literature proves that there are many approaches to explain the RRI concept. Some authors define it as "responsible research and innovation" 20 while others as "responsible innovation" 21 . The most common definition is the one provided by Von Schomberg, who explains RRI as:

[...] a transparent, interactive process by which societal actors and innovators become mutually responsive to each other with a view to the (ethical) acceptability, sustainability and societal desirability of the innovation process and its marketable products (in order to allow embedding of scientific and technological advances in our society) ${ }^{22}$.

18 Ibidem.

19 J. Elkington, Cannibals with Forks: The Triple Bottom Line of Sustainable Development, Chapstone Publishing, Oxford 1997, p. 327.

20 R. Von Schomberg, Introduction: Towards responsible and innovation in the information and communication technologies and security technologies field, [in:] R. von Schomberg (ed.), Towards Responsible Research and Innovation in the Information and Communication Technologies and Security Technologies Field, Publications Office of the European Union, Luxembourg 2011, p. 9; J. Van den Hoven et al., Options for Strengthening Responsible Research and Innovation, European Commission, Brussels 2013, p. 5.

21 M. Burget, M. Bardone, M. Pedaste, Definitions and Conceptual Dimensions of Responsible Research and Innovation: A Literature Review, "Science and Engineering Ethics" 2017, vol. 1, no. 23, p. 15; J. Stilgoe, R. Owen, P. Macnaghten, Developing a framework for responsible innovation, "Research Policy" 2013, vol. 9, no. 42, p. 1570; M. Noorman, T. Swierstra, D. Zandbergen, Questioning the normative core of RI: The challenges posed to stakeholder engagement in a corporate setting, [in:] L. Asveld et al. (eds), Responsible Innovation 3: A European Agenda?, Springer, Cham 2017, p. 231.

22 R. Von Schomberg, Introduction: Towards responsible..., p. 9. 
The RRI concept focuses on a firm's stakeholder inclusion along the whole innovation process. Van den Hoven et al. argue that RRI is a comprehensive approach approaching research and innovation in ways that involve all stakeholders in the processes at an early stage to obtain knowledge on the consequences of the outcomes of the innovation, the range of options open to them and to effectively evaluate both outcomes and options in terms of societal needs and moral values as well as to use these considerations as functional requirements for the design and development of new research, products and services ${ }^{23}$. Burget Bardone and Pedaste perceive RRI as an attempt to govern research and innovation in order to include all the stakeholders and the public in the early stages of research and development. The inclusion of different actors and the public is a intended to increase awareness of how research and innovation may benefit society as well as avoid any negative consequences ${ }^{24}$. The RRI concept is also a point of interest for the European Union. EU documents define RRI as an on-going process of aligning research and innovation to the values, needs and expectations of society ${ }^{25}$. In general, RRI anticipates and assesses any potential implications or societal expectations with regard to research and innovation. The literature describes the RRI concept in term of four dimensions. Owen et al. claim that innovating responsibly requires being anticipatory, reflective, inclusively deliberate and responsive ${ }^{26}$. Being anticipatory and reflective requires asking question of how the current dynamics of research and innovation practices will impact the future. This means focusing on and anticipating the attended and unattended outcomes of innovations in their economic, social and environmental dimensions. Being inclusively deliberative implies the involvement of a wide range of stakeholders in the early development of science and technology. Focus on inclusion and deliberation means upstream engagement of stakeholders and members of the public in discussions which are directed at analyzing the social, political, environmental as well as ethical implications that the development of the innovation could bring 27 . Finally, being responsive means responding to the views of both the public and stakeholders. Responsiveness requires having the capacity to change the shape of an innovation

23 J. Van den Hoven et al., Options for Strengthening..., p. 3.

24 M. Burget, M. Bardone, M. Pedaste, Definitions and Conceptual Dimensions..., p. 15.

25 European Union, Rome Declaration on Responsible Research and Innovation in Europe, Brussels 2014, https://ec.europa.eu/research/swafs/pdf/rome_declaration_RRI_final_21_No vember.pdf (accessed: 5.12.2019).

26 R. Owen et al., A Framework..., p. 38.

27 M. Burget, M. Bardone, M. Pedaste, Definitions and Conceptual Dimensions..., p. 14; R. Owen et al., A Framework..., pp. 35-38; R. Von Schomberg, A vision of responsible research..., pp. 67-68. 
or its direction in response to the values of stakeholders and the wider public ${ }^{28}$. To sum up, the main concept behind RRI points to the necessity of working in unison with respect for future generations.

\section{Corporate Social Responsibility compared to Responsible Research and Innovation - overlaps and differences}

While considering the similarities of CSR and RRI, one can easily notice that both concepts focus on a firm's responsibilities towards social and environmental good and stakeholder engagement. In terms of innovation process management, both may be applied to create wide, multi-stage consultation processes to limit the risks related to unforeseen consequences from innovations. However, regardless of their similarities, both concepts differ greatly. First of all, RRI is rather a top-down approach created in the world of policies, in which policy-makers strive to induce a system intensifying ethical and responsible research and innovation, through the questioning of the ethical and social aspects of the responsible production and use of knowledge. RRI proposes a new contract between science, technology, innovation and society in order to generate innovations that are ethically acceptable and socially desirable 29 . CSR, on the other hand, is more of a bottom-up approach. It acts as a management model for firms that, beyond a business profit, enables the detection of opportunities in addition to generating a community and environmental impact. CSR functions are perceived as a self-regulating mechanism for firms, proving their compliance not only with the law, but also with international norms and ethical standards. The CSR and RRI concepts differ also in regard to business impacts. The main focus of RRI is its ethical assessment and potential, as well as actual, social impact. CSR focuses mainly on a business's impact on communities and the environment. Furthermore, the CSR concept is generally applicable to all activities of a firm, including research and innovation process management. Nevertheless, it is not specifically designed for the area of research and innovation as is the case with RRI ${ }^{30}$.

28 J. Stilgoe, R. Owen, P. Macnaghten, Developing a framework..., p. 1572; R. Lubberink et al., Lessons for responsible innovation in the business context: A systematic literature review of responsible, social and sustainable innovation practices, "Sustainability" 2017, vol. 9, no. 5, 721, p. 4.

29 R. Von Schomberg, A vision of responsible research..., p. 63.

30 A. Gurzawska, M. Makinen, Ph. Brey, Implementation of Responsible Research..., p. 4. 
While comparing CSR and RRI, the latter is potentially both broader and narrower in scope. RRI is broader in scope than CSR because it demands a link to the needs of citizen and societal desirability. On the other hand, it is narrower in scope than CSR as it deals only with research and innovation rather than the entire business cycle ${ }^{31}$.

Despite these differences, both concepts cover management issues in a business context. CSR rules and methods might be applied to build certain practical standards to guide the innovation process. Following CSR rules, and implementing particular practices in this field allows managers to understand that everything a firm does, has some flow-on effect both inside and outside the company. Improvements in CRS practices may lead to a number of responsibility-oriented innovations. Nowadays, firms should do more to tackle issues such as: social injustices, poverty, climate change, etc. Successful products of the future will be those that see these challenges as opportunities for innovation, rather than risks to be alleviated. In this context, CSR rules and practices help incorporate social concerns and democratic accountability into the research and innovation process. Despite the fact that CSR deals with the whole cycle of business life and not just the research and innovation stage, for a business to address its corporate responsibilities effectively it needs to focus on: 1) its business impacts (identifying the social and environmental impacts of its operations and assessing their significance), 2) policies to mitigate those impacts (adopting management standards to re-organize its activities and minimize those impacts) and 3) the stakeholders' concerns (identifying the most important stakeholders, understanding and prioritizing their concerns, and developing a strategy to satisfactorily address them). Thus, from a business perspective, CSR and RRI concepts should be integrated by applying CSR tools such as responsibility standards (e.g. ISO9001, ISO 14001, ISO 26000 EMAS, SA8000), principles (e.g. Caux Round Table Principles, CERES Roadmap for Sustainability), codes of conduct etc., to assist firms in implementing RRI principles ${ }^{32}$. CSR tools are self-regulatory and have been established to promote a common understanding and a common means of business performance evaluation in terms of responsibility. They are formal documents, establishing criteria and practices focused on continuous improvement related to the respect for health and safety in the workplace, environmental protection and stakeholder engagement. Applying such tools can provide a governance framework that ensures the advancement of the RRI approach in its business context. These tools all address widely accepted principles that are in line with RRI elements, such as transparency, ethical behavior, respect for stakeholders' interests, accountability, respect for law regulations as well as respect for human rights.

31 K. latridis, D. Schroeder, Responsible Research..., p. 26.

32 Ibidem. 


\section{Conclusions}

Nowadays, to achieve both progress and profit firms focus on innovations. They are increasingly being called upon to address the negative impacts of their operations and come up with responsible, innovative solutions embedded in business strategy $^{33}$. As this paper's conceptual contribution is demonstrating the relationships between the CSR and RRI concepts, we assess that its objective has been achieved. Our paper contributes to the literature and business practice through exploring the ideas of the CSR and RRI concepts and the possibilities to integrate them in order to create ethically acceptable and socially desirable innovations. While the RRI concept remains largely unfamiliar to companies, the CSR concept is well known and many firms are well advanced in this area. Therefore, the idea of integrating both concepts and applying particular CSR tools to ensure the implementation and advancement of the RRI approach in its business context provides useful managerial implications concerned with delivering profitable but also ethically acceptable and socially desirable innovations.

Certainly, we are aware of the limitations of the study. First, the paper comprises only a theoretical review and needs to be followed by empirical research, which is planned by the authors. Secondly, using a single research method results in a lack of triangulation, which may have a negative impact on the quality and objectivity of the study. Finally, due to the rapid dynamic development of the research field, we find a static, one-time analysis to be insufficient. Therefore, the replication of the study in the future is recommended to observe changing trends and shifts in the research field over time.

\section{References}

Adam B., Groves C., Futures tended: care and future-oriented responsibility, "Bulletin of Science, Technology \& Society" 2011, vol. 1, no. 31, pp. 17-27.

Basu K., Palazzo G., Corporate Social Responsibility: A Process Model of Sensemaking, "Academy of Management Review" 2008, vol. 1, no. 33, pp. 122-136.

Benn S., Bolton D., Key Concepts in Corporate Social Responsibility, Sage Publications, London 2011.

Boehe D.M., Barin-Cruz L., Corporate Social Responsibility, product differentiation strategy and export performance, "Journal of Business Ethics" 2010, no. 91, pp. 325-346.

Burget M., Bardone M., Pedaste M., Definitions and Conceptual Dimensions of Responsible Research and Innovation: A Literature Review, "Science and Engineering Ethics" 2017, vol. 1, no. 23, pp. 1-19.

33 Ibidem. 
Carroll A.B., Corporate social responsibility: Evolution of a definitional construct, "Business \& Society" 1999, vol. 3, no. 38, pp. 268-295.

Chakraborty S.K., Verghese K., Singh J., Mrityunjay A., Aga A., Gupta A.K., Management paradigms beyond profit maximization, "The Journal of Decision Makers" 2004, vol. 29, no. 3, pp. 97-117.

Elkington J., Cannibals with Forks: The Triple Bottom Line of Sustainable Development, Chapstone Publishing, Oxford 1997.

European Commission, Communication from the Commission to the European Parliament, the Council, The European Economic and Social Committee and the Committee of the Regions. A renewed EU strategy 2011-14 for Corporate Social Responsibility, Brussels 2011, https://eur -lex.europa.eu/legal-content/EN/TXT/PDF/?uri=CELEX:52011DC0681\&from=EN (accessed: 5.12.2019).

European Union, Rome Declaration on Responsible Research and Innovation in Europe, Brussels 2014, https://ec.europa.eu/research/swafs/pdf/rome_declaration_RRI_final_21_Novem ber.pdf (accessed: 5.12.2019).

Groves C., Future ethics: risk, care and non-reciprocal responsibility, "Journal of Global Ethics" 2009, vol. 1, no. 5, pp. 17-31.

Gurzawska A., Makinen M., Brey Ph., Implementation of Responsible Research and Innovation (RRI) Practices in Industry: Providing the Right Incentives, "Sustainability" 2017, vol. 9, 1759.

Heinberg R., Peak Everything: Waking up to the Century of Decline in Earth's Resource, Clairview, London 2007.

latridis K., Schroeder D., Responsible Research and Innovation in Industry. The Case for Corporate Responsibility Tools, Springer, London 2016.

Leone M.I., Belingheri P., The relevance of Innovation for Ethics, Responsibility and Sustainability, "Industry and Innovation" 2017, vol. 5, no. 24, pp. 437-445.

Lubberink R., Blok V., Ophem J., Omta O., Lessons for responsible innovation in the business context: A systematic literature review of responsible, social and sustainable innovation practices, "Sustainability" 2017, vol. 9, no. 5, 721.

McWilliams A., Siegel D., Corporate social responsibility: A theory of the firm perspective, "Academy of Management Review" 2001, no. 26, pp. 117-127.

McWilliams A., Siegel D., Wright P.M., Corporate social responsibility: strategic implications, "Journal of Management Studies" 2006, vol. 1, no. 43, pp. 1-18.

Noorman M., Swierstra T., Zandbergen D., Questioning the normative core of RI: The challenges posed to stakeholder engagement in a corporate setting, [in:] L. Asveld, R. van Dam-Mieras, T. Swierstra, S. Lavrijssen, K. Linse, J. van den Hoven (eds), Responsible Innovation 3: A European Agenda?, Springer, Cham 2017, pp. 231-249.

Owen R., Stilgoe J., Macnaghten Ph., Gorman M., Fisfer E., Guston D., A Framework for Responsible Innovation, [in:] R. Owen, J. Bessant, M. Heintz (eds), Responsible Innovation. Managing the Responsible Emergence of Science and Innovation in Society, Wiley, New York 2013, pp. 27-50.

Porter M.E., Kramer M.R., Strategy and society: The link between competitive advantage and Corporate Social Responsibility, "Harvard Business Review" 2006, vol. 12, no. 84, pp. 78-92.

Stilgoe J., Owen R., Macnaghten P., Developing a framework for responsible innovation, "Research Policy" 2013, vol. 9, no. 42, pp. 1568-1580.

Taneja S.S., Taneja P.K., Gupta R., Research in corporate social responsibility: A review of shifting focus, paradigms and methodologies, "Journal of Business Ethics" 2011, no. 101, pp. 343-364.

Van den Hoven J., Jacob K., Nielsen L., Roure F., Rudze L., Stilgoe J., Options for Strengthening Responsible Research and Innovation, European Commission, Brussels 2013.

Van Marrewijk M., Concepts and definitions of CSR and corporate sustainability: Between agency and communion, "Journal of Business Ethics" 2003, no. 44, pp. 95-105. 
Von Schomberg R., A vision of responsible research and innovation, [in:] R. Owen, J. Bessant, M. Heintz (eds), Responsible Innovation, Managing the Responsible Emergence of Science and Innovation in Society, Wiley, New York 2013, pp. 51-74.

Von Schomberg R., Introduction: Towards responsible and innovation in the information and communication technologies and security technologies field, [in:] R. von Schomberg (ed.), Towards Responsible Research and Innovation in the Information and Communication Technologies and Security Technologies Field, Publications Office of the European Union, Luxembourg 2011, pp. 7-15.

World Business Council for Sustainable Development, World Business Council for Sustainable Development, Corporate social responsibility: Meeting changing expectations, New York 1999.

Abstract

The growing attention on responsibility in business is forcing firms to build their competitiveness through integrating the principles of responsibility in their strategies. Given the necessity to apply new approaches in business, we focus on discussing two management concepts concerning responsibility: Corporate Social Responsibility and Responsible Research and Innovation. The aim of the paper is to explain these concepts, focusing on their similarities and differences as well as the possibility to integrate them into business practice. The research process is based on a literature review and focuses on providing a critical assessment of the reasons for integration CSR and RRI in a business context.

Keywords: responsibility, corporate social responsibility, responsible research and innovation 